\title{
Wat verbeeldt de christelijke gemeente zich als ze zegt dat God haar aanspreekt?
}

\author{
Maarten den Dulk ${ }^{1}$ \\ Rijks Universiteit Leiden \\ Navorsingsassosiaat: Departement Praktiese Teologie \\ Universiteit van Pretoria
}

\begin{abstract}
In what manner does the Christian congregation imagine God to be addressing her?

In the reading and preaching of Scriptures people speak to one another about God. These actions are surrounded by words, gestures and rituals directed to God. However, the congregation also claims that God is addressing her. Hence, this article poses the question: In what manner does the congregation imagine God to be addressing her? Which images and parables are used for this purpose? In dealing with this question the article focuses on the words in Numbers 7:89 relating how Moses heard a voice coming from the space between the two cherubim standing on the atonement cover on the ark of the Testimony. This verse offers an indication of how believers can presume God to be speaking in liturgical space.
\end{abstract}

\section{VRAAGSTELLING}

Schriftlezing en prediking zijn handelingen die in kerkdiensten steevast terugkeren. $\mathrm{Nu}$ weet ik ook wel dat er méér dingen zijn tussen hemel en aarde. Maar gun het de praktische theoloog om de aandacht voor een ogenblik op deze handelingen te vestigen. Wat gebeurt daar? Mensen spreken elkaar aan over een bepaalde God. Maar daar blijft het niet bij. Ze omgeven deze handelingen met woorden, gebaren en rituelen die gericht

\footnotetext{
1 Prof dr Maarten den Dulk is hoogleraar emeritus in Praktische Theologie aan die Rijks Universiteit Leiden, Nederland, en is betrokke by prof dr C J Vos se navorsingsprojek "HomLit" in die Departement Praktiese Teologie, Universiteit van Pretoria.
} 
zijn op deze God. Ze spreken samen God aan. Maar ook dat is nog niet alles. Ze zeggen vroeg of laat ook zoiets als: hier spreekt God ons aan. Dat laatste roept de vraag op: wat verbeeldt de christelijke gemeente zich als ze zegt dat God haar aanspreekt? Achter de ironie van deze vraag schuilt mijn liefde voor de verbeeldingskracht van de christelijke gemeente. Zij stelt zich voor dat er een God is die haar aanspreekt. Haar voorstelling is gedrenkt in herinneringen over deze aanspraak van God. En al haar handelen is omgeven door het verlangen dat die God haar inderdaad aanspreekt. Ik deel deze herinnering en dit verlangen. Ik waag mij aan het vertrouwen dat mensen in een doorgaand gesprek met God zijn betrokken. Maar dat verhindert niet dat ik er mijn vraag bij heb. Mijn vraag is: hoe stelt ze zich voor dat God haar aanspreekt? Welke beelden en gelijkenissen gebruikt ze daarvoor? De context waarin ik de vraag stel is de liturgische handeling van schriftlezing en prediking.

Terzijde gezegd: dat God spreekt is op zich genomen geen voorwerp van praktisch theologisch onderzoek. Dat gebeuren kan slechts worden aangeduid in beelden en gelijkenissen, als hoeksteen van of als missing link in de liturgie. Juist die verbeeldingskracht van de gemeente gaat ons hier aan. Maar dat leidt ons niet af van het gebeuren dat God spreekt. De beelden en gelijkenissen zijn juist nodig om de aandacht te blijven richten op dat gebeuren dat God spreekt. Zij hebben kritische kracht. Ze houden namelijk de handeling van schriftlezing en prediking open naar dat gebeuren. Zonder de kritische kracht van de verbeelding blijven schriftlezing en prediking ronddraaien in de eigen wereld van sprekers en hoorders. En die komen dan steeds opnieuw zich zelf tegen. Exegese, hermeneutiek en retoriek zoemen rond, de preek wordt een samenvatting van wat reeds geschreven, gelezen en begrepen is en wie nog hoopt op een creatieve vondst van de voorganger krijgt op den duur de herkomst van diens invallen ook wel door. De kritiek is dus nodig om ruimte te houden tussen het moment dat de Schrift wordt voorgelezen en nog niet is uitgelegd. Een ruimte die de belofte heeft van een nieuw lied. Een geluid waarvan Guido Gezelle in Kleengedichtjes lichtvoetig zei: "Gods woord is mij ingevallen." De praktisch theoloog spreekt de liturgische gemeente daarop aan: néémt ze haar theologische verantwoordelijkheid inzake deze beelden en gelijkenissen? 
De vraag wordt in dit artikel toegespitst: hoe stelt de gemeente zich voor dat God spreekt in de liturgische ruimte, bij de lezenaar, op het moment dat het schriftelijke getuigenis geklonken heeft, maar nog niet is uitgelegd?

\section{DE INKEER VAN MOSES}

Ik ga uit van een voorstelling die in de schriftelijke overlevering van de gemeente zelf is gegeven. Het moment waarop wordt verbeeld hoe de leraar Mozes inkeert in een liturgische ruimte en daar het gesprek zoekt met de God van zijn gemeente. Ik concentreer me op enkele woorden, die overgeleverd zijn in Numeri 7:89. Er zijn over het gesprek van Mozes met God verschillende voorstellingen overgeleverd. God spreekt tot Mozes in een brandend braambos, of tussen de elementen in wolken en bliksem, maar ook in de beschutting van een tent. Numeri 7:89 (en de daarmee samenhangende voorstelling in Exodus 25) stamt uit de betrekkelijk jonge priestercodex. De context van Numeri 7 is de tempel, althans de tempel in de voorlopige vorm van een tent, de tabernakel. Maar de tekst komt in een netwerk van teksten voor, waarin andere contexten een rol spelen. ${ }^{2}$ Uit een oudere laag stamt Exodus 33, waar Mozes God ontmoet in een ontmoetingstent buiten het kamp en met Hem spreekt als met een vriend. In Numeri 12 wordt Mozes' autoriteit bevestigd tegenover hen die met hem twisten over zijn huwelijk: Mozes' gezag wordt daar ondersteund door de mededeling dat God met hem sprak niet via dromen en visioenen, maar rechtstreeks in de wolkkolom. In Deuteroneum 34:10

\footnotetext{
2 Ik dank A Van der Kooij die mij op dit netwerk van teksten opmerkzaam maakte. Ik kies uit de vele voorstellingen Num 7:89, omdat daar de liturgische context een rol speelt. Levine (1993:246-266) wijst erop dat in Num 7:89 twee verschillende tradities bijeenkomen betreffende de functie van de tabernakel, of tent der ontmoeting (ohel moeed). De ene traditie ziet die tent als als orakelplaats en de andere als cultische plaats. 1) In Ex 33:6-11 (w s traditie van de Elohist) is er sprake van een orakeltent, die buiten het kamp geplaatst is en bedoeld is voor verbale communicatie met God. In Ex 25:22 (29:42-43; 30:6-36) zijn het priesterlijke bronnen, die zich op deze conceptie van de tent beroepen. Leviticus opent zelfs met de de mededeling dat God Mozes riep vanuit de tent der ontmoeting. 2) In Lev 16 daarentegen is er geen sprake van verbale communicatie. De tent van de ontmoeting heeft uitsluitend een rituele functie. Hier krijgt alleen de hogepriester toegang tot het binnenste van de tent voor het ritueel van de verzoening. In Num 7:89 komen de twee tradities bij elkaar. Deze tekst schijnt in het boek Numeri enigszins verdwaald te zijn. Davies (1995): Het betreft een geïsoleerde tekst die oorspronkelijk een inleiding (waarin God reeds genoemd wordt) en een vervolg (waarin de inhoud van Gods mededeling tot Mozes wordt gemeld) moet hebben gehad. Het is een vervulling van Ex 25:2. Waarom op deze plaats in Numeri onverwachts vermeldt wordt dat God spreekt blijft een raadsel. Noth denkt dat de redactor hiermee wil aangeven dat God de eerder genoemde gaven aanvaardt.
} 
wordt dit gezag nog verder ondersteund door de mededeling, dat God met Mozes sprak van aangezicht tot aangezicht. Nooit was er een profeet die dit beleefde. Deze teksten stellen Mozes voor als een uitzonderlijke persoon, die in een unieke relatie met God staat. Wat met hem gebeurt gebeurt met niemand anders. Zelfs niet met Aäron. Wellicht is deze voorstelling apologetisch gericht tegen kringen waarin Mozes' autoriteit wordt aangevochten. Dit gebeuren is dus niet iets wat anderen zomaar kunnen beleven of kunnen nadoen. Maar door deze gedachtenis worden de lezers en hoorders betrokken bij dit gebeuren. Ze worden deelgenoot gemaakt van het gesprek. Ze worden al luisterend erfgenamen van deze ontmoeting. Ze kunnen het - ideaaltypisch - als beeld en gelijkenis verstaan van eigen ervaringen.

Ik geef een eerste algemene beschrijving van het gebeuren. Mozes zoekt het gesprek met God tijdens de tocht door de woestijn in een mobiele ruimte, de zogenaamde "tent van de ontmoeting". Hij nadert dan tot een bijzondere ruimte ìn die ruimte, de plaats waar de schriftelijke overlevering van de gemeenschap wordt bewaard in een kist: "de kist van het getuigenis". 3 De liturgische ruimte is versierd. In de tapijten aan de wanden en aan de plafonds zijn voorstellingen geweven van mythologische wezens, gevleugelde wilde dieren, een soort sfynxen. Ze worden "cherubs" genoemd en meestal vertaalt men dat woord niet. Ze hebben de functie van buitengewoon krachtige beschermengelen en zo zou ik zelf het woord willen vertalen. De meest opvallende versiering van deze liturgische plaats is echter aangebracht op het deksel van de kist waarin het schriftelijke getuigenis wordt bewaard. Twee sculpturen van beschermengelen zijn tegenover elkaar geplaatst. Ze staan naar elkaar toegewend, met opslaande vleugels, maar houden de blik gericht op de kist, waarin het schriftelijke getuigenis

\footnotetext{
${ }^{3}$ Sommigen commentatoren laten Mozes slechts naderen tot vóór het voorhangsel. Zo wordt de tekst uit Numeri in overeenstemming gebracht met de tekst uit Leviticus, waar alleen de hogepriester éénmaal per jaar achter het voorhangsel mag komen. Zie: Milgrom (1990), zowel in zijn commentaar bij de tekst, als ook in excurs 15 (Milgrom 1990:365). Mozes heeft niet vanzelfsprekend toegang tot de tent. Voordat de tent wordt ingewijd kan Mozes zelfs niet binnenkomen vanwege Gods gevaarlijke aanwezigheid (Ex 40:3435). Eerst na de inwijding van de tent krijgt hij toegang (Lev 9:23). Maar er blijft priesterlijk verzet tegen de gedachte dat Mozes zou worden toegelaten tot achter het voorhangsel. Ex 33:11, Dt 34:10, Num 12:8 zouden moeten worden opgevat als hyperbool, in de zin dat Mozes wel de tent binnenkomt, maar vóór het voorhangsel moet blijven staan.
} 
verborgen is (Freedman \& O'Connor 1984:330-331). ${ }^{4}$ Bij die plaats zoekt Mozes het gesprek met God. De woorden die dit gebeuren aanduiden laten zich horen als een klein gedicht:

Als Mozes de tent van de ontmoeting binnenging om hem te spreken, dan hoorde hij de stem tot hem spreken boven het deksel dat op de kist van het getuigenis is, tussen de twee beschermengelen, en hij sprak tot hem.

Welke informatie biedt dit vers? De zin is gebouwd op de herhaling van het werkwoord spreken: “... Mozes ging naar binnen om hem te spreken ... hij hoorde de stem tot hem spreken ... en hij sprak tot hem." Het vers weerspiegelt aldus de structuur van een gesprek. Mozes ontmoet iemand anders en raakt in gesprek. Hij hoort geen stemmen in zijn hoofd. De stem komt van tussen de beide cherubsbeelden, niet van tussen zijn oren. Maar de herkomst van de ander blijft onbekend. De stem komt uit het niets. Er hurkt geen hermeneutisch geschoolde dwerg in de boekenkist.

De stem komt ergens van boven de kist van het getuigenis, uit het niets. Wie is die ander? De geheimzinnige partner krijgt geen naam. De suggestie wordt wel gewekt dat het om een God gaat en wel dezelfde God die zich elders in Numeri betoont als bevrijder en gids van zijn volk. Maar de specifieke Godsnaam en zelfs het zelfstandig naamwoord God komen in dit vers niet voor. De spreker wordt er slechts aangeduid met de derde persoon enkelvoud. ${ }^{5}$ Maar wat is de zin van de geheimzinnigheid waardoor de

\footnotetext{
4 Uit vergelijking met buitenbijbelsmateriaal kunnen we zeggen dat de cherubs Mischwesen zijn, die gevleugeld kunnen zijn, twee- of viervoeters, vogels of draken. De opstelling van de twee cherubs in de tent van de ontmoeting is anders dan die in de tempel van Salomo. Daar zijn de cherubs niet naar elkaar toegewend, maar naar voren gericht.

${ }^{5}$ Deze terughoudendheid leidt zelfs tot een dubbelzinnigheid in de laatste regel van het vers: "Hij sprak tot hem". Buber/Rosenzweig (1981) vertalen: "Zij sprak tot hem" ("sie redete zu ihm"). In die zin namelijk, dat de stem sprak tot Mozes. Maar het kan ook anders: "Hij sprak tot hem" kan ook betekenen: Mozes sprak tot God. In veel vertalingen probeert men het probleem van de dubbelzinnigheid op te lossen door het zelfstandig naamwoord "God" of "de Heer" toe te voegen. De Statenvertaling behield in de eerste uitgave nog de terughoudendheid die aan de hebreeuwse tekst eigen is. In latere edities vulde men de verwijzing naar God in door "hij" met een hoofdletter te schrijven.
} 
identiteit van de ander wordt verborgen? Waarom wordt God hier opzettelijk verhuld aangeduid als "de stem" die zich op een bepaalde "plaats" laat horen?

Een dogmatische doordenking kan hier wellicht verder helpen. Marquardt (1991:103-116) wijst op het volgende. ${ }^{7}$ Er is hier sprake van Gods wil om mensen te ontmoeten. Die wil heeft geen toevallig karakter, maar krijgt een plaats: een plaats van de ontmoeting, oorspronkelijk voorgesteld als een tent van de ontmoeting die meetrok met de zwervende stammen. De ontmoeting krijgt een persoonlijk karakter in de relatie met Mozes. God spreekt met Mozes van aangezicht tot aangezicht als met een vriend. Daar wordt in het spreken van mond tot mond de distantie tussen God en mens overwonnen. Marquardt stelt dat dit in de wereld van het jodendom een ongehoorde uitspraak is en blijft. De ontmoeting tussen God en mens krijgt hierdoor iets tussenpersoonlijks. Het is dus niet de beschrijving van een innerlijke ervaring. Het gaat om wederkerigheid, echte communicatie tussen twee partners. Maar de ontmoeting is ook weer niet te manipuleren. De ontmoeting komt tot stand door een komen en gaan van de elkaar ontmoetende partners. God komt nabij om bij de mensen te wonen. "Die mobile Dabeiseinsweise des Kommens und Gehens treibt zu auf eine festere Präsenz Gottes in Israel" (Marquardt 1991:105). Aldus bespreekt Marquardt de structuurelementen in deze en dergelijke bijbelse uitspraken en beschouwt ze uiteindelijk als elementaire deeltjes voor de christologie.

Het voorstellingsvermogen wordt hierdoor tegelijk geprikkeld en afgeremd. Maar het zal blijken dat de prikkel steeds weer sterker is dan de rem. Het vers uit Numeri heeft een proces van verbeelding op gang gebracht, waardoor men zich kon voorstellen hoe God spreekt in de liturgische context.

\footnotetext{
6 Jacob (1997:879-880) beschouwt deze wijze van spreken als "die unsinnlichste Versinnlichung der ... unkörperlichen Stimme des unsichtbaren Gottes." Als hulp bij het verstaan kan men denken aan de stem van ouders of leraren, belangrijke morele persoonlijkheden, zoals Samuel denkt dat Eli hem roept. Maar wat wil de tekst met deze verhulde wijze van spreken zeggen? Suggereert het een mystieke ervaring? Of duidt het op een geheimzinnig orakelritueel (zoals de Vulgata veronderstelt). Of is dit vers een theologische poging om de "woordopenbaring" te beklemtonen tegenover de offercultus, waarover het in de context van Numeri gaat (zoals Jagersma 1983 voorstelt? Of is het een signaal dat de hele omgang van God en mens ingebed is in de notie van het gesprek?

${ }^{7}$ Zie ook voetnoot 18 .
} 


\section{DE VERBEELDING VAN DE GEMEENTE}

Ik begin met twee beelden uit de traditie van het jodendom. Ze doemen op in commentaren op Numeri, die schriftelijke zijn overgeleverd in de elfde en twaalfde eeuw van onze jaartelling, maar die materiaal bevatten uit oudere overleveringen.

\subsection{Spreekbuis}

De eerste voorstelling probeert antwoord te geven op de vraag: hoe kan Mozes de stem van God horen? Een stem van zeer ver, die toch zeer nabij klinkt? In de Midrash Rabbah (Freedman \& Simon [1939] 1961) ${ }^{8}$ wordt een technisch beeld gebruikt: een stem daalt uit de hemel af als door een soort buis van vuur tussen de twee cherubs door en zo hoort Mozes de stem tot hem spreken van vlakbij. Het is het beeld van de spreekbuis dat tot op heden nog een zekere populariteit geniet, zoals blijkt uit de zegswijze dat sommige mensen een hotline met God hebben of via channeling over hogere kennis kunnen beschikken. Maar daar klinkt meestal iets van ironie in door. In de discussie in de Midrash Rabba is van ironie evenwel geen sprake. Men verwondert zich eerder over het feit dat God, die hemel en aarde vervult met zijn heerlijkheid, zich volledig concentreert om op deze plaats deze mens aan te spreken. En wel zodanig dat deze mens hoort wat niemand anders te horen krijgt. Zelfs de cherubs worden buitengesloten. Het gaat om

\footnotetext{
${ }^{8}$ Wellicht de jongste van de midrasjiem op de Pentateuch, mogelijk uit de $12^{\mathrm{e}}$ eeuw (Deel I, p VII). Het beeld van de spreekbuis schijnt in eerste instantie slechts te functioneren als technische verklaring voor een tegenstrijdigheid in de bijbelse teksten. Enerzijds wordt gezegd dat God vanuit de tent spreekt (Lev 1:1), terwijl anderzijds in Numeri gezegd wordt dat Mozes God hoort in de tent. De uitleg is dan, dat God via het Heilige der Heiligen (dus van binnen uit de tent) spreekt, terwijl Mozes in het Heilige (dus in de voorste ruimte van de tent) verblijft. Mozes blijft zo "buiten" en hoort toch de stem "van binnen". Om de bemiddeling van binnen naar buiten mogelijk te maken is een spreekbuis nodig. Die buis heeft uiteraard een meer dan aardse kwaliteit. Gods stem kan slechts worden bemiddeld door een buis van vuur: "A voice would then descend from heaven, as though through a kind of tube of fire, to between the two cherubim, and Moses would hear the voice speaking to him from within" (Freedman \& Simon 1961:632). In het vervolg van de discussie komt echter nog een heel ander en meer inhoudelijk argument aan de orde. De kwestie is waarom de stem van God zo nadrukkelijk aan een plaats gebonden wordt. De stem wordt gelokaliseerd tot boven de ark en ook nog eens tussen de beide cherubim. Simeon, R b. "Azzai (behorend tot de Tannaïten, omstreeks $110 \mathrm{n}$. Chr.) verwijst naar Jer 23:24 "God vervult hemel en aarde" en zegt: "Yet see to what lengths He went in his love of Israel! This same Glory, that was so vast, compresses itself so as to appear to be speaking from above the ark-cover between the two cherubim!" God die hemel en aarde vervult met zijn heerlijkheid balt zich zelf samen om zich tot Mozes en tot Mozes alleen te richten (Freedman \& Simon 1961:640). Ook de engelen zien en horen God niet. De stem is niet tot hen gericht, maar tot Mozes. Dezelfde Simeon verwijst naar Ex 33:20 "Geen mens zal God zien en leven." En zegt: "Scripture tells us that the Voice went from the mouth of the Holy One, blessed be He, as through a tube into the ear of Moses, and the angels who stood midway could not hear" (Freedman \& Simon 1961:641). Met dank aan van M A van Rhijn voor deze verwijzing.
} 
vertrouwelijke informatie voor de leraar van Israël. Het betreft de vraag: wat moet een mens doen in de huidige situatie? Zeker, de toekomst van het hele volk en van de hele mensheid is daarbij in het geding. Maar de problemen worden behandeld in geheim overleg. De veiligheids-maatregel doet denken aan overleg in een crisissituatie, omgeven door radiostilte. Wat gebeurt er als men deze verbeelding van de spreekbuis overbrengt naar de liturgische situatie van de christelijke gemeente? Het roept het beeld op van een gemeente rondom een priesterlijke ambtsdrager, die exclusieve kennis meedraagt en doorgeeft, of aan een gemeente als kleine cel die haar kennis over God bij zich bewaard als disciplina arcana, omringd door de ironie van de samenleving.

\subsection{God in gesprek met zich zelf}

Een heel ander beeld komt naar voren in het middeleeuwse commentaar van Rashi (Silbermann 1933). ${ }^{9}$ Rashi vraagt aandacht voor de zin: Mozes hoorde de stem, die tot hem sprak. Althans zo wordt deze zin meestal vertaald. Hij wijst er echter op dat de letterlijke vertaling luidt: Mozes hoorde de stem die met zich zelf in gesprek was (participium hitpael). Mozes vangt iets op van het gesprek dat God met zich zelf voert. Het is of hij achter een gordijn vaag het geluid hoort van iemand die met zich zelf in gesprek is. Hij kan het niet helpen dat hij het hoort en hij weet ook niet of hij het wel goed hoort, maar het roept bij hem de verwachting op dat het ergens over gaat. Zo luistert Mozes naar het verhaal dat God, hoorbaar onhoorbaar, vertelt. ${ }^{10}$

In deze voorstelling wordt een zekere distantie tussen de partners bewaard. Het beeld roept een mystieke sfeer op, die niet alleen Rashi heeft bekoord. De Leidse geleerden Tremellius en Iunius hebben deze vertaling in het begin van de zeventiende eeuw op hun beurt gepropageerd en wat hun betreft had het zo in de Staten Vertaling kunnen komen. Wat overigens niet is gebeurd. ${ }^{11}$ In onze dagen heeft de

\footnotetext{
${ }^{9}$ Rashi (Rabbi Sjlomo ben Jitschak) leefde van 1040 tot 1105 in Troyes, Frankrijk.

10 Mosès (1999:84-85), becommentarieert deze vondst van Rashi als volgt: "Cette voix qui parle continuellement, sans s'adresser a personne, c'est la parole indifférenciée, sans commencement, et sans fin, pareille á une pure promesse de sens, que seul Moïse, prophète doué d'une sensibilité surnaturelle, est capable, lorsqu'il est placé dans une situation tout à fait particulière (celle de la Tente d'assignation), de capter et d'interpréter."

${ }^{11}$ Testamenti Veteris Biblia Sacra, vertaald en van kanttekeningen voorzien door Immanuel Tremellius en Fransiscus Iunius, 1607: “...tunc audiebat vocem sermocinantem secum...”
} 
oudtestamenticus Maarsingh het opnieuw opgenomen voor deze vertaling. Hij haalde het echter uit de mystieke sfeer. Hij vergelijkt Mozes met een profeet die een politiek visoen krijgt. "God met zich zelf in gesprek", dat is dan: God in overleg met zijn hemelse raadgevers over de wereldgeschiedenis. Dat levert een dramatisch beeld op. Zoals dat van de profeet Micha uit het boek Koningen. Die neemt iets waar van hemels topoverleg over de actuele politiek op aarde. Hij proeft de spanning van de elkaar tegensprekende adviezen en hoort hoe God zich uiteindelijk compromitteert aan het plan om een gevaarlijk staatsman te stoppen door hem te misleiden met desinformatie. ${ }^{12}$

Deze twee aspecten, het mystieke en het politieke aspect, laten zich herkennen in de eigentijdse liturgische sfeer. Het doet denken aan een gemeente die bevindelijkheid beoefent en aan een gemeente die het politieke bewustzijn wakker houdt. En soms weet ze dat nog te combineren ook. Een begaafde gemeente die zoekt naar zin. Die geen duidelijke antwoorden heeft, maar ook niet zonder hoop is antwoorden te vinden. $\mathrm{Ze}$ blijft luisteren naar signalen die er op wijzen, dat er iets van God uit gaat voor het heil van mens en samenleving. ${ }^{13}$

\subsection{Troon}

In de eigentijdse commentaren wordt overigens de voorkeur gegeven aan nog een heel andere voorstelling: als Mozes de tent van de ontmoeting binnenliteraturegaat nadert hij tot voor de troon van God. Men wijst erop dat de beschrijving van de kist en de cherubs enigszins doet denken aan een antieke koningstroon, bekend uit de archeologie. De kist van het getuigenis is de voetenbank van de heerser. De beide cherubs dragen met hun vleugels de onzichtbare God. Ze suggereren de beweging van God die komt op de vleugels van de wind. En tegelijk fungeren ze als de borgen van de troon en verdedigen die links en rechts tegen aanval en schending. Al deze elementen roepen het beeld op van een lege troon. En deze troon spreekt op haar beurt van de aanwezigheid van de

\footnotetext{
12 Maarsingh (1984:49) associeert Mozes' ervaring met die van de profeet Micha de zoon van Jimla uit 1 Kon 22:19-23. Deze associatie veronderstelt de leeswijze, dat Mozes "de stem ziet" zoals in Ex 20:15-18.

13 Ter Schegget (2001:4-7) geeft een emotioneel aangrijpende en theologisch verhelderende analyse van deze vorm van omgang met God.
} 
Onzienlijke (o.a. Maarsingh 1984:49; Milgrom 1990). ${ }^{14}$ De hele entourage wordt gezien als een expressie van machts-verhoudingen. Elk element drukt de machtsongelijkheid uit tussen God en mens.

Wanneer men deze voorstelling als voorbeeld neemt voor de liturgie levert dit het volgende beeld op. Mensen begeven zich in een ruimte, waarin zij hun plaats weten. Zij naderen voor de troon van God, zoals bevoorrechte dienaren voor de koning. Zij leggen hun zaak aan hem voor. Zij kunnen zich beroepen op de grondwet, maar die ligt onder de voeten van de monarch. Ze mogen eerbiedig in overleg treden, maar ze mogen het aangezicht van hun heer niet zien. Ze mogen vragen en pleiten, maar ze moeten zich ten allen tijden verantwoorden en kritiek accepteren. En in alles wachten zij op de beslissing die deze heerser zal nemen. Ze leven van diens genade. ${ }^{15}$

\subsection{De ruimte tussen de beide cherubs}

Enkele jaren geleden, in 1999, heeft Stephane Mosès het vers uit Numeri op een heel andere wijze aan het licht gebracht (Mosès 1999:85-86). Om te zien wat hij hier ziet, moet men de vorige beelden van de buis, het visioen en de troon weer loslaten. De informatie die het vers uit Numeri biedt is veel kariger. Het laat niets meer zien dan een kist met een deksel en daarop twee beelden, die de leegte tussen hen beiden vasthouden. Stephane Mosès vestigt de aandacht op die lege ruimte. We moeten er naar kijken met de ogen van de dichter: “...Er is niets te zien, en dat moet je zien...” (De Coninck 1998:337).

14 Jacob (1997:882-883) wijst er met klem op dat de kist van het getuigenis in deze voorstelling niet geïdentificeerd kan worden met de troon, maar hooguit met de voetenbank van God. Maar in de traditie blijft de verzoeking merkbaar om de kist toch als troon te interpreteren: M. Luther vertaalt het "deksel op de ark" vanaf 1523 met Gnadenstuel. En ook Bruegemann (1997:665) spreekt in dit verband over de Seat of grace.

15 Deze voorstelling brengt ons in de meest klassieke liturgische sfeer. De coulissen van de liturgie plaatst de gemeente in een gezagsverhouding met haar God, haar gesprekspartner die tevens haar rechter is. De Joodse gemeente kan het gebeuren overbrengen naar de ruimte van de synagoge. In het spoor van Mozes begeeft zij zich tot voor de ark, de boekenkast, waar het getuigenis van het verbond wordt bewaard. Door Mozes weet ze dan voor wiens aangezicht zij staat. Van Mozes leert zij daar van week tot week wat de koning der wereld haar gebiedt. Men weet dat men staat voor de rechter over leven en dood. In de doophuizen van Ravenna zowel van de Ariaanse als de Orthodoxe kerken uit de vijfde en zesde eeuw staat gemeente en voorganger voor de afbeelding van de lege troon. Het is de zetel van de macht van hem "die is en die was en die komt." 
Volgens het vers uit Numeri wordt Gods stem gehoord vanuit dat niets, van tussen de beide cherubs. Hier vindt het spreken plaats. Hier woont de stem voor een ogenblik. Hier wordt de ontmoeting met God beleefd in een vluchtig moment. Stephane Mosès beschrijft de leegte tussen de beide cherubs als de ruimte, die hen scheidt en verbindt, die de afstand en de nabijheid van die twee aangeeft. Vanuit deze beschrijving neemt zijn interpretatie een grote vlucht. De logica van het bijbelse beeld is duidelijk - zegt hij. De cherubs verbeelden twee menselijke subjecten die met elkaar spreken. En daar, in de ruimte van de relatie tussen twee personen, manifesteert zich de stem Gods. Het zijn niet de cherubs zelf die elk voor zich het goddelijke woord overbrengen. Het goddelijke brengt zichzelf voort en wel in de ruimte tussen de cherubs. Zo is dat ook in de menselijke relaties. Levinas heeft daarop gewezen: de openbaring ontspringt in het tegenover van twee personen. God spreekt niet in de activiteit van één autonoom subject, maar in de ethische relatie tussen twee subjecten.

Het is een voorstelling, waardoor ik mij graag zou laten meenemen. Maar het gaat iets te snel. De sprong van de cherubsbeelden naar de menselijke relatie maak ik niet in één keer mee. Cherubs beelden geen mensen uit. Het zijn beelden van wilde dieren met een menselijk gezicht. Ik houd dus nog even de pas in. En vraag me af wat die beelden als beelden willen zeggen in de liturgie. Ik ga nu met mijn eigen verbeelding aan de haal.

\subsection{Liturgie als kunst}

De twee beelden van de cherubs, de beschermengelen, zijn kunstvoorwerpen met een liturgische functie. Ze zijn geen producten van een typisch Joodse religieuze kunst. Het zijn voorwerpen met een in die dagen volstrekt algemene religieuze, zo niet politieke functie.

Maar ze staan niet toevallig op de kist met het schriftelijke getuigenis. Ze moeten daar een zekere sfeer scheppen, zodat men weet: hier wordt de Schrift bewaard als getuigenis over God en hier wordt tegelijk de ruimte geschapen voor een nieuw actueel verstaan van dit getuigenis. Ze wekken een zekere verwachting: daar waar wordt nagedacht over dit schriftelijke getuigenis zal het komen tot een nieuw verstaan en een nieuw spreken. Duidelijker gezegd: ze houden de verwachting open dat het bij de 
bezinning op deze teksten over God zal komen tot een nieuwe ontmoeting met God zelf. Deze concentratie wordt opgeroepen door die beide beelden en de ruimte daartussen, dus door een expressie van kunst. Het betreft hier kunst als onderdeel van de liturgie en het gaat om bepaalde liturgische coulissen als expressie van kunst. De beelden staan niet op zich zelf. Ze verwijzen naar het geheel van het liturgisch handelen, het zingen, de gebeden, de rituelen. Dit handelen houdt de verwachting open. Het is een acte van mensen, gedragen door de herinnering en omgeven door de verwachting van het komen en spreken van God. Op de spits gedreven kan al dit handelen als kunst beschouwd worden, kunst in de zin van poëzie en dans, maar ook in de zin van architectuur en beeldende kunst. Schleiermacher heeft de blik daarvoor geopend, door de liturgische communicatie als kunst te beschouwen. ${ }^{16}$ Liturgie is kunst die mensen bewust maakt van de hunkering naar een betrouwbaar, levensscheppend en richtinggevend woord. Door middel van deze kunst kan men zich het onvoorstelbare proberen voor te stellen: dat dat woord klinkt. Alleen kunst laat zien wat niet te zien is: vuur uit de hemel, stem met zich zelf in gesprek, stoel die wacht op iemand die komt. ${ }^{17}$

In Numeri 7 wordt de hele kunst van de liturgie samengebald in twee beelden. Die beelden stellen machten voor met de ondoorgrondelijke uitstraling van een sfynx. Je kan ze zien als gevleugelde afgezanten van almachtige goden. Maar je kan ze ook zien als belichaming van alles wat macht heeft op aarde, de macht van het woord, van overtuigingen, van driften en motieven en van puur geweld in de geschiedenis. Ze hebben van allebei wat. Ze brengen de hemel tergend dichtbij, maar houden de mens op afstand. Ze tonen de bijna onbegrensde mogelijkheden van de mensen, maar die reiken slechts tot aan de hemel. Er zijn er twee nodig voor deze tango. De één waakt bij de grenzen van wat mensen kunnen weten en doen. Die geeft niet toe aan de gedachte dat

\footnotetext{
${ }^{16}$ Groot (1994:314-315): "In de Ethik noemt Schleiermacher de eredienst een kunstwerk, dus in de zin van een object van esthetische waarneming. Het is uit 'vluchtig' materiaal - gebaren, gezang en gesproken woord - gevormd. Daarom heeft het geen blijvend karakter, maar moet het in en door de samenkomsten steeds opnieuw tot stand worden gebracht". Voor Friedrich Schleiermacher (1910:108) was de waarneming van liturgie als kunst noodzakelijk om een theorie over het liturgisch handelen te kunnen ontwikkelen.

17 Alma en Zock (2000:103-114), onderzoeken de vraag: in hoeverre doet kunst evenals religie "een beroep op ons vermogen te geloven". De theologische betekenis van de lege en toch begrensde plaats in de kunst is onder de aandacht gebracht door Witvliet (1999) met name in hoofdstuk 8: "Azaria Mbatha en de vijftiende statie van de kruisweg") en door Wahl (2000).
} 
God zou spreken. Niet uit cynisme, maar met heimwee met een zeker verdriet omdat het mensen niet gegeven is met de rede de grens te overschrijden. De ander vertrouwt dat God zelf deze grens doorbreekt en zich te kennen geeft op zijn tijd. Niet in naïveteit, maar met ongeduld en driftig, omdat we deze heilzame kennis zo nodig hebben. De één zegt: geen macht op aarde kan God ter sprake brengen. De ander zegt: geen macht op aarde kan God weerhouden te spreken. Ze vinden allebei dat ze gelijk hebben. Maar geen van beiden kan het eigen gelijk doorzetten ten koste van de ander. Wat kunnen ze wel? Ze kunnen de impasse vasthouden. En dat doen ze. Die impasse verschijnt als een ruimte tussen het gelijk van de één en het gelijk van de ander. Zo zetten ze een veld van krachten uit en nodigen ons uit om in dat veld te komen.

Mensen die zich in dit veld wagen geven zich voluit over aan het geding. Ieder kiest partij met een eigen variant. Ze vechten, in kerken en collegezalen, in columns en in voetnoten, met verhalen en strategieën. Ze vechten voor wat ze waard zijn en soms beleven ze dat als their finest hour. Dat gebeurt als mensen elkaar tegenspreken over de verbeelding dat God spreekt. Soms lijkt het er dan ook op alsof door dit geding de mensen uiteengedreven worden in twee soorten, die elkaar niet willen verstaan. Zoals J H Leopold (geciteerd bij Komrij 1979:377) zei - "twee soorten worden er ontdekt: intelligente mensen zonder vroomheid en vrome mensen zonder intellect." Maar of ze willen of niet ze zijn op elkaar aangewezen. Mozes zocht uitgerekend deze hevig aangevochten plaats op en daar verstond hij God.

Zoals gezegd hebben de twee beelden van de cherubs een functie in de liturgie. En wanneer ze inderdaad de functie zouden krijgen zoals ik hier heb aangeduid, dan is de liturgie geen veilige haven. De liturgie is dan niet de plaats waar men ongestoord over God zou kunnen spreken, terwijl dat elders in de cultuur wat moeilijker is. Integendeel juist de liturgie is de plaats waar het geding om Gods onmogelijke woord gevoerd wordt. Het is de plaats waar de impasse gevoeld en doorstaan wordt. En het is een puur wonder als het daar komt tot een opening in de impasse van keiharde posities. De twee sfynxen blijven onbewogen kijken. Zei iemand iets? Zei God iets? Wie zegt dat? Wie ben jij dat je dat zegt? Wie ben jij dat je dat ontkent? Wie leiding geeft aan de liturgie beleeft dit iedere keer als een zwaar examen. Het gaat over de vraag of er iets gezegd zal worden waardoor nieuw leven gewekt wordt. Dit is zo moeilijk en tegelijk zozeer aangelegd op 
het wonder, dat ik wel moet denken aan een gedicht van Willem Barnard (zie Van der Graft 1997:756):

\author{
Is er een opening \\ er is geen opening \\ Er is een deksel dat \\ realiteit heet \\ Er is een gat \\ dat tot de hemel reikt \\ Er is geen opening \\ er is niets dan opening
}

De verbeelding van de gemeente vindt hier haar grens, maar tegelijk ook haar grond. De tekst uit Numeri 7 drukt met minimale taalmiddelen de verwachting van de gemeente uit dat God tussen beide komt en spreekt. De gemeente ziet het voor zich: God staat op en schept ruimte tussen de machten om plaats te maken voor de ontmoeting. God wordt een plaatsnaam, zoals Mokum. Een plaats waar engelen het niet wagen te treden. God wordt een stem die mensen aanspreekt. ${ }^{18}$ Dat spreken geeft ruimte. Waar die stem zich laat gelden worden de beide machten, dat "ja" en dat "nee", op afstand gezet en krijgen ze de

18 Dit communicatieve gebeuren veronderstelt dat de distantie tussen God en mens wordt overwonnen. Marquardt (1991:107) bespreekt dit gebeuren onder de noemer "Zwei-Setzung" Gottes, een term die hij heeft ontleend aan $\mathrm{Cl}$. Thoma. De overwinning van de distantie tussen God en mens blijft echter iets unheimlichs houden. De discussie in 1 Kon 8:27 over de tempel als plaats van God bewijst dit. Hoe kan men dit gebeuren beschrijven zonder het geheim van de distantie te schenden? Het komt tot een gebeuren, waardoor God zich van zich zelf onderscheidt en zich zelf tweemaal poneert: Mijn naam zal daar wonen (1 Kon 8:27). Over de naam wordt gesproken als een zelfstandige werkelijkheid, een medium, waardoor mensen kunnen communiceren (door bidden, danken, loven) zonder God te na te treden. In het vroege Jodendom komen daarbij de uitdrukkingen: wijsheid, heerlijkheid, Woord, Schechina. Deze Zwei-Setzung betekent: er is sprake van een gelijktijdigheid van God in de hemel en op de aarde. Dat houden de engelen niet tegen. Het leidt tot uitspraken van emotionele solidariteit van God met Israël. Als de tempel van Jeruzalem verwoest is in 70 kan gezegd worden dat God buiten de tempel blijft brullen als een leeuw totdat het Israël weer vergund is weer op deze plaats te treden. Het leidt tot de uitspraak dat God met zijn volk zal zijn, zoals voorheen in Egypte, zo ook in de komende verdrukkingen van de verstrooiing: ik zal er zijn...Waar dat gezegd wordt is er sprake van formele christologie: het rijk Gods is midden onder u. Of zoals in Johannes 1:14: het woord Gods woont onder ons. Het gaat op de wijze van het wonen van God temidden van zijn volk (Marquardt 1991:111). 
functie om samen de ruimte open te houden. Ze hebben elkaar daarbij nodig. Ze moeten elkaars argumenten horen en van elkaar leren. Er is een ethisch verband tussen beiden gelegd. Tesamen bewaken ze de voorwaarden waardoor mensen de stem van de Levende kunnen horen. Deze gedachte wordt homiletisch ontgonnen en vruchtbaar gemaakt door Bregman (2000:7-29). En als er gestreden moet worden dan ligt hier de grond voor een goede strijd.

Wat zegt God? Heeft de gemeente daar een idee van? De kleine tekst in Numeri 7 zwijgt erover. Maar wie argeloos doorleest in Numeri hoort dat God aan Mozes de huiselijke opdracht geeft: "Ontsteek de kandelaar". Dat is het begin van alle praxis. Verlichting. Als theologen daarbij helpen kunnen is hun aanwezigheid zinvol. Ze hoeven het licht niet uit te blazen.

\section{Literatuurverwysings}

Alma, H A \& Zock, T H 2000. De religieuze zeggingskracht van de opera Dialoques des Carmélites. GTT 100(3), 103-114.

Buber, M/Rosenzweig, F 1981. Die Schrift: Verdeutscht von Martin Buber gemeinsam mit Franz Rosenzweig. Heidelberg: Lambert Schneider.

Bregman, C 2000. In de werkplaats van de taal - over preken en poëzie: Een verkenning in het spoor van Martinus Nijhoff, in Postille, 7-29. Zoetermeer: Boekencentrum.

Brueggemann, W 1997. Theology of the Old Testament: Testimony, dispute, advocacy, Minneapolis, MN: Fortress.

Davies, E W 1995. Numbers. London: Pickering. (The New Century Bible Commentary.)

De Coninck, H 998. De gedichten, I. Amsterdam: Arbeiders pers.

Freedman, D N \& O'Connor, P 1984. s v kerub. ThWAT.

Freedman, H \& Simon, M (ed) 1939. Midrash Rabba, translated into English with notes, glossary and indices. London: Soncino.

Gezelle, Guido 1970. Kleengedichtjes, met inleiding door Keersmaekers, A Hasselt: Heideland-Orbis. 
Wat verbeeldt de christelijk gemeente zich als ze zegt dat God haar aanspreekt?

Groot, N 1994. Wetenschap en Theologie bij Friedrich Schleiermacher: Een interpretatie van de Kurze Darstellung des theologischen Studiums. Leiden: Faculteit der Sociale Wetenschappen.

Jacob, B [1940/43] 1997. Das Buch Exodus, hrsg. Mayer, S e.a. Stuttgart: Calwer Verlag.

Jagersma, H 1983. Numeri, I. Nijkerk: Callenbach. (Prediking van het Oude Testament.)

Komrij, G 1979. De Nederlandse Poëzie van de $19^{e}$ en $20^{e}$ eeuw in 1000 en enige gedichten. Amsterdam: Bakker.

Levine, B A 1993. Numbers 1-20. New York: Doubleday. (The Ancor Bible.)

Maarsingh, B 1984. Numeri. Een praktische bijbelverklaring. Kampen: Kok.

Marquardt, F-W 1991. Das christliche Bekenntnis zu Jesus, dem Juden: Eine Christologie 2. München: C L Kaiser Verlag.

Milgrom, J 1990. Numbers. Philadelphia, New York: The Jewish Publication Society. (The JPS Torah commentary).

Mosès, S 1999. L'Éros et la Loi: Lectures bibliques. Paris: Seuil.

Silbermann, A M 1933. Pentateuch with Rashi's commentary, Numbers. Jerusalem: Silbermann.

Schleiermacher, F 1910. Kurze Darstellung des theologischen Studiums zum Behuf einleitender Vorlesungen, hrsg. von H Scholz. Nachdruck. Darmstadt: Wissenschaftliche Buchgesellschaft.

Ter Schegget, G H 2001. Inkeer. In de Waagschaal 30(10), 4-7.

Van der Graft, G 1997. Mythologisch: Gedichten, oud, nieuw en herzien. Baarn: de Prom.

Wahl, R 2000. Het lege midden: In het spoor van een metafoor. Wageningen: eigen uitgave.

Witvliet, Th 1999. Gebroken traditie: Christelijke religie in het spanningsveld van pluraliteit en identiteit. Baarn: Ten Have. 